\title{
Creating a New Innovation Orientation Through Idea Competitions
}

Nicolajsen, Hanne Westh; Scupola, Ada

Published in:

Digital Business Transformation

DOI:

10.1007/978-3-030-47355-6_7

Publication date:

2020

Document Version

Peer reviewed version

Citation for published version (APA):

Nicolajsen, H. W., \& Scupola, A. (2020). Creating a New Innovation Orientation Through Idea Competitions. In R. Agrifoglio, R. Lamboglia, D. Mancini, \& F. Ricciardi (Eds.), Digital Business Transformation (pp. 93-106). Springer. Lecture Notes in Information Systems and Organisation Vol. 2020 No. 38 https://doi.org/10.1007/9783-030-47355-6_ 7

\section{General rights}

Copyright and moral rights for the publications made accessible in the public portal are retained by the authors and/or other copyright owners and it is a condition of accessing publications that users recognise and abide by the legal requirements associated with these rights.

- Users may download and print one copy of any publication from the public portal for the purpose of private study or research.

- You may not further distribute the material or use it for any profit-making activity or commercial gain.

- You may freely distribute the URL identifying the publication in the public portal.

Take down policy

If you believe that this document breaches copyright please contact rucforsk@kb.dk providing details, and we will remove access to the work immediately and investigate your claim. 


\title{
Creating a New Innovation Orientation through Idea Competitions
}

\begin{abstract}
This paper conducts an in depth case study of the implementation of an idea competition in a consulting company. Based on 27 interviews with company managers as well as users and users of the idea competition, the case shows how the implementation of the idea competition in the company has changed the innovation orientation of the company along several dimensions including creativity and empowerment, innovation infrastructure, innovation influence and innovation intention.
\end{abstract}

Keywords: Idea Competition, Innovation Orientation, culture, ICT

\section{Introduction}

Being innovative is highly important for most companies in order to stay competitive, also for service companies. Having a supportive innovation culture or strong innovation orientation is essential regarding how innovative a company is (Dobni, 2010). An innovation culture is in general described as a culture where risk- taking, empowerment and open communication among other factors are appreciated (Brentani \& Kleinschmidt, 2004; Dobni, 2010). Chesbrough (2003) talks about a closed and an open approach to innovation. The open approach values external partnerships and inspiration whereas the closed one values control and secrecy.

In the last two decades or more the open innovation approach has received high emphasis as a way to strengthen the innovation potential. This is among other things fueled by access to the Internet and software developments such as online collaborative functionalities and lately social media that have made interaction and community building infrastructures even easier to build and access (McAfee, 2006; Andriole, 2010). Many service companies have taken advantage of these interactive tools to involve their customers in different phases of the innovation process (Nambisan, 2002, 2008; Alam and Perry, 2002; Kristensson, 2008).

The studies investigating interactive tools for internal use such as the innovation jams in IBM (Bjelland \& Wood, 2008) or organizational Wikis (Standing \& Kiniti, 2011) are flourishing. Idea competitions are one category of these tools. The success of using these tools to involve external partners such as customers to come up with ideas has been widely researched (eg. Piller et al. 2005; Ogawa \& Piller, 2006; Lakhani \& Kanji, 2008). However we argue that there is a new and not highly researched trend of companies using such tools for internal use. It may be argued that these tools carry with them an inherent approach to innovation much in line with the open innovation paradigm due to functionalities supporting open communication, participation, empowerment etc. (Ibrahim, 2010). Therefore we investigate the following research question: How does a consulting company use an internal idea competition to influence the innovation orientation in the organization? 
We analyze a case study of a consulting company's implementation of an idea competition by investigating its conceptualization and the initial attempts to change the innovation orientation in the company.

The paper is structured as follows. First we describe the theoretical grounding defining service innovation, innovation orientation and idea competitions. Then we present the research method. This is followed by the analysis, discussion and conclusions

\section{Theoretical Grounding}

To frame our understanding of innovation orientation and culture we first define the concept of innovation and service innovation. Service innovation is defined by Gallouj \& Weinstein (1997) as any change affecting either the technologies (methods or materials) involved in the service provision, the competencies (employees, organizational or client) or any part of what makes the final service. This definition allows us to investigate and describe all sorts of innovations no matter which element or extent of change involved as long as it results in added value.

Only few researchers have worked with the concept of innovation culture, which is strictly related to innovation orientation. Brentani and Kleinschmidt (2004) define a firm's innovation culture as "involving entrepreneurship, risk taking, and openness to new ideas" (p.312). The innovation culture is considered as a subculture with a style of corporate behavior valuing new ideas, change, risk and not at least failure as a necessary part of working innovatively. Also, an innovation culture is described as one nurturing a climate of openness, informal communication, involvement, thinking out of the box and adaptive to change. Whether this "subculture" is part of the organizational culture as such or only counts for innovation departments or when innovation is planned for is unclear.

Dobni (2010), in line with Brentani and Kleinschmidt argues that an organization's strategy and degree of innovativeness is affected by what he coins "the innovation orientation". Dobni (2010) argues that four dimensions are of importance to describe the innovation orientation of a company (see table below): the intention to be innovative, the infrastructure to support innovation, the behaviors needed to influence a market/value orientation and the environment to support implementation. Dobni's overall understanding is that innovation orientation, which is part of the organizations culture, affect the competitive strategy of the company and therefore the organizations performance (Dobni, 2010, p. 333).

Table 1. Dimensions of innovation culture (Dobni, 2010)

1. Innovation intention 


\begin{tabular}{|c|c|}
\hline Innovation propensity & $\begin{array}{l}\text { The degree to which the organization has a formally } \\
\text { established - within their business model - architec- } \\
\text { ture to develop and sustain innovation. This would } \\
\text { be communicated through vision, goals, objectives, } \\
\text { and operationalized through the business model and } \\
\text { business processes. }\end{array}$ \\
\hline Organizational constituency & $\begin{array}{l}\text { Considers the level to which employees are en- } \\
\text { gaged in the innovation imperative and how em- } \\
\text { ployees think of themselves vis-á-vis their col- } \\
\text { leagues in respect to value, equity, and contributions } \\
\text { made within the organization. }\end{array}$ \\
\hline \multicolumn{2}{|l|}{ 2. Innovation infrastructure } \\
\hline Organizational learning & $\begin{array}{l}\text { The degree to which the training and the educa- } \\
\text { tional opportunities of employees are aligned with } \\
\text { the innovation objectives. }\end{array}$ \\
\hline Creativity and empowerment & $\begin{array}{l}\text { Determination of the creative capacity of em- } \\
\text { ployees and the amount of creativity that employees } \\
\text { are allowed to express in their work. AIt assesses } \\
\text { the degree of empowerment held by employees, and } \\
\text { the ability of employees to improvise and enact at } \\
\text { will. }\end{array}$ \\
\hline \multicolumn{2}{|l|}{ 3. Innovation influence } \\
\hline Market orientation & $\begin{array}{l}\text { Market sensing and contextual awareness behav- } \\
\text { iors of employees. It considers the extent to which } \\
\text { employees generate and disseminate knowledge on } \\
\text { customers, competitors, the industry, as well as their } \\
\text { understanding of the value chain or cluster in which } \\
\text { their operate }\end{array}$ \\
\hline Value orientation & $\begin{array}{l}\text { The degree to which employees are focused on } \\
\text { and involved in the process to create value for cus- } \\
\text { tomer/clients. }\end{array}$ \\
\hline
\end{tabular}




\begin{tabular}{|l|l|}
\hline \multicolumn{2}{|c|}{ 4. Innovation implementation } \\
\hline Implementation context & $\begin{array}{l}\text { The organization's ability to execute value-added } \\
\text { ideas. It considers the ability to proactively co-align } \\
\text { systems and processes with the changes in the com- } \\
\text { petitive environment. }\end{array}$ \\
\hline
\end{tabular}

According to Dobni a strong innovation orientation engage behaviors such as valuing risk taking, creativity, freedom, teamwork, it instills trust and respect as well as fast decision making (p. 334) very much in line with Brentani and Kleinschmidt (2004). The innovation culture definitions presented here provide a normative stand, defining the companies as having a strong or weak innovation culture/orientation with given values of what makes a strong innovation culture. However, no considerations are made in terms of differences across the organizations with respect to for example innovation and coordination needs, resources and qualifications, leaving open questions as to whether it is positive that everybody are innovative at all times? Dobni ends up asking whether it is possible to manage strategy through designing the innovation orientation, a question in line with what we ask in this article.

Such questions point back to an old debate within the organizational culture literature as to whether culture can be managed and how it changes. Pliskin et al. (1993) state that the organizational culture literature can be divided into two streams. The first one is descriptive and has the purpose of understanding and describing organizational culture. The second one, which has a normative approach, assumes that organizational culture can be managed, where Schein (1985) is a strong advocate. Hatch(1993) further developsScheins model of organizational culture and argues for a dynamic relationship. She understands organizational culture as constituted by assumptions, values, artifacts and in addition symbols and the ongoing processes that link them. Hatch's understanding indicates that culture is changeable but that it difficult to manage culture due to the dynamics in play including the interpretation processes going on. It may not be fully manageable and controlled and it makes more sense to argue that it can be designed for (Wenger, 1998).

This understanding is in line with the studies by Doherty and Doig (2003) and Doherty and Perry (2001) examining how new technologies may become a catalyst in transforming espoused cultural values into reality whereas or help strengthened organizational values. These studies are however different then ours as they look at innovating a certain practice, whereas our focus is on a tool to support innovation in general.

Markus (2004) argue that it is not the technology per se but rather the organizational set- up around the new IT which creates the changes. Markus (2004) also argues that implementation of new systems fail if there are too big differences between the IT system and the existing organizational culture. 


\subsection{Online idea competitions}

Online idea competitions allow an organization to post problems or themes online, where a group of participants may provide solutions to a given problem. These solutions may then be further elaborated by other participants or voted on online or may be moved to another community for further evaluation and development. The winning ideas are awarded some form of a prize, and the organization may implement the idea for its own gain.

According to Ebner et al (2009) and Bullinger et al (2010) the key design elements describing idea competitions are: the organizer, the timeline, incentives, problem specification, target group, composition of groups, media, evaluation criteria, idea review, idea review committee, elaborateness, context and community functionality.

Especially the element of community functionality, which is only part of Bullinger et al's framework, is essential as it makes idea competitions suitablefor open communication and interaction, thus providing possibilities for collaboration and competition, which again allow for community building (Bullinger et al, 2010). According to Bullinger et al. (2010), low and high cooperation orientation supports high degrees of innovativeness, whereas medium cooperation orientation results in low degree of innovativeness. The importance of community functionality is further supported by a more recent study by Hutter et al. (2011) finding that the tension between competition and collaboration is what makes an online innovation community flourish.

\section{$3 \quad$ Research Method}

To investigate the research question a case study methodology was considered appropriate as we investigate a real-life phenomenon - implementing an idea competition tool - where control over the context is impossible (Yin, 1997). The main data collection method was semi-structured interviews with open-ended questions. We conducted 27 interviews (Table 1). The respondents were selected on the base of their involvement in the planning, implementation and participation to the idea competition. At the beginning of the research, the informants were selected by the competence manager and the innovation director that we also interviewed. Later snowball sampling (Goodman, 1961) was used to find respondents with different profiles. 17 of the interviews lasted about 1-1/1/2 hours each, the other 910 were short interviews of approx. $1 / 2$ hour. All interviews were tape recorded and transcribed. We asked about the purpose of the idea competition, how the tool and the organizational set-up were designed and supported as well as about the organizational and individual outcome and challenges. 
Documentation review and field notes were complementary data collection methods including material about the idea competition process; schemes to submit ideas, samples of submitted ideas, the winning ideas and criteria for idea selection. The researchers also gained access to the idea competition platform for a short period of

\begin{tabular}{|l|l|}
\hline \multicolumn{1}{|c|}{ Number of interviews } & 27 \\
\hline From HQ & 17 \\
\hline From Regional offices & 8 (4 regional offices) \\
\hline Other & 1 customer \\
& 1 supplier \\
\hline Duration of interviews & Normal 1-1.5 h (17) \\
& Short ca. 30 min (10) \\
\hline The informants' positions & Competence manager \\
& Innovation director \\
& Innovation champion \\
& Project manager \\
& Project member \\
& IdeaExchange team members \\
& Marketing director \\
\hline
\end{tabular}

Table 2. Interview data

time to get an idea of its functionalities. The interviews are combined with the secondary material to create so-called rich descriptions (Walsham, 1995).

The data analysis follows Miles and Huberman (1994) instructions for analysing qualitative data and interviews. In the process of data collection, data coding (Miles \& Huberman, 1994) it became clear that the biggest issue was establishing an innovation orientation rather different from the established innovation practice in The Company. In order to analyze these attempted changes and challenges we use Dobni's (2010) understanding of innovation orientation. Before we move into the analysis, we shortly present the case company.

\subsection{The Engineering Consulting Company}

The Company (a pseudonym) is a large engineering consulting company with 1600 employees specializing in different fields including construction and design, infrastructure and transport, energy and climate, environment and water and IT and telecommunications. The Company is part of a leading engineering, design and consultancy group, headquartered and founded in Denmark.

\section{$4 \quad$ Analysis and Results}

\subsection{IdeaExchange Implementation}

In The Company, the main source of innovation occurs, develops and is financed through consulting projects. However, it is believed that the company's employees 
possess a great deal of knowledge about the internal processes that could be a source of organizational efficiency. The decision to use the idea competition platform was taken at a directors meeting about the company strategy.. A group of eight "smart employees with drive" from different department in Denmark was invited to form a project group - "The innovation team". Their task was to develop a sustainable concept around the idea management platform from Nosco (the software provider) called "Idea Exchange" to crowdsource ideas from the employees. The Idea Exchange platform includes a number of community functionalities that enhance interaction and collaboration. For example, it is possible to submit one's own ideas or comment on ideas posted by others to suggest improvements or to further develop the idea. Each employee is given an amount of virtual money at the beginning of the competition, which can be invested into ideas contributed by others. At any point in time, the spot value of an idea - together with the comments that support it- is proxied by the aggregate investment positions held on it relative to all other ideas. The ideas get ranked automatically in the system according to their spot value.

The implementation of Idea Exchange is much more than implementation of the Idea Exchange platform. It is a concept including components such as: the roll out plan including invitations, follow up communication, deadlines, log ins, articles in the internal newsletter, information provided on the intranet, information screens running commercials about the Idea Exchange event and the Innovation Day, a formula for presentation of the ideas, nomination of the winning ideas and the strategic implementation of the winning ideas.

By applying the design variables from Ebner et al (2009) and Bullinger et al. (2010), The Company is the organizer and the employees are the participants which participate as individuals with user name without needing to state their position in the company. The context is a call for ideas for upcoming strategy. Five strategic themes were formulated by top management along with an online format to guide the form of input desired. The activities on the online Idea Exchange lasted sixes weeks, whereas the whole idea competition event including the off line activities followed the strategic year and a little longer, as the winning ideas were turned into strategic action areas for the upcoming year. Three rounds of review process took place. After the online idea posting and trading period expired, prizes were given to the ideas with the highest spot value in each theme, a prize to the best trader and a prize to the best commentator. These prizes were symbolic such as an Ipad. The highest ranked idea within each of the five themes entered into a pool of 10 ideas to be further developed for a final evaluation along with five ideas selected through an off line evaluation process. In fact, the Innovation Team screened the rest of the ideas (approx. 100) and selected 20 promising ideas according to a number of criteria developed by the Innovation Team and communicated atthe very beginning of the Idea Exchange event. These 20 selected ideas were presented to the management group who in turn selected5 of these ideas (Wildcards) for further development together with the 5 highest ranked ideas. A number of work hours were then allocated to these 10 finalist idea "owners" and each idea owner was assigned a couple of experts to help them further develop the ideas and define the implementation needs. The Idea Exchange event culminated with the Innovation Day, where the 10 finalist ideas were presented to an audience of company 
employees and external people and three "winner" ideas were selected by an innovation panel for final implementation. The panel was composed by company directors and an external expert. The prizes included participation to innovation courses and implementation of the idea. The incentives to participate are both external such gifts, and internal as recognition and influence if the idea get implemented.

\subsection{Changes in the Innovation Orientation}

\section{Innovation intention}

According to Dobni there is a need of "a formally established architecture to develop and sustain innovation". The whole event of the Idea Competition with its anchoring in the company strategy both regarding the themes' formulation as well as the eventual implementation of the winning ideas is a way to ensure formality and business alignment in The Company.

The primary intention of the Idea Competition was getting access to many different ideas for innovation. The assumption is that all employees possess insight into The Company's internal processes and therefore might have ideas on how The Company may do better. This is in contrast to the existing innovation culture as some respondents state that having employee's ideas heard, developed and implemented is not easy. The leaders often act as "gatekeepers". The idea competition is recognized as a way to overcome this also by the employees as showed by the following statement:

"You get innovation on the agenda and it becomes more approachable, more fun and more interesting making people want to use their spare time on it. The main advantage is that it shortcuts the distance between high and low in the system, meaning ideas that normally don't get to the management group, gets there" Project member \#14

Likewise it has created a recurrent architecture supporting employee driven innovations which otherwise aren't supported as shown in the following qoutes:

".. how to move on when you bump into a good idea - well it has become rather easy here in The Company, because you know that there are these possibilities occasionally" project leader \#23

"I think many have thought about ideas before, but they would not come and tell, but now it is easy, you just go and write it" project member \#15

Regarding the level of engagement of employees - there is an intention to reach out and make it easy for all employees to participate. The focus on internal process innovation along with the possibilities to take on different roles is a way to appreciate any kind of engagement and acknowledging other roles in innovation than just providing ideas. All employees should feel invited no matter if they are used to take part in innovation or not.

“.. innovation takes place on many levels and it may take many different forms, not necessarily the one who has a good idea (..) it may also be the one sitting beside "well, what if you did this" (..) It was meant to include widely to get people participating" Innovation Team member \#10

This approach is rather different as innovation in the company is acknowledged as done by a few highly innovative and resource strong employees. 
"I believe it is really important to have an open forum, where you can voice all your ideas, before it was some "fiery souls" who knew the system and knew how to apply for money, now everyone can throw in an idea" Project member \#19

Others are however reluctant to participate, as they are afraid of the quality level of their ideas. No resources are given to the employees to participate in the idea competition and therefore it becomes "con amore" and the more "enthusiastic rather than the crowd" as emphasized by an Innovation Team member. This is a way to limit the participation. It may constrain the number of ideas for good and bad. However, some of the employees also argue that not everybody is tuned towards innovation.

\section{Innovation infrastructure}

There are no particular qualifications needed to participate in the Idea Exchange event as promising ideas can be further developed with help of organizational experts. On the other hand, the constituency of the different roles is a way to create a learning opportunity and to create a broader innovation awareness in The Company.The employees are lured into the Idea Exchange as dealers, thus taking part in this "funny", non-risky part of the Idea Exchange event. Getting them into the Idea Exchange platform is a way to get them exposed to the innovation process, which may make them learn from the ideas of others and create awareness and confidence about what innovation can be.

"if you don't think of your self as super innovative, then you can take part by playing the game and be a good dealer" Innovation team member \#15

The majority had contributed as s dealers rather than as idea contributors. Many had entered the online Idea Exchange but did not even participate as dealers. One respondent questions the ease to use the system. Many informants state that they used almost an hour the first time to understand the Idea Exchange concept. One argues it is due to too much text.

"There is too much explanation on the different categories, you need to invest too many resources to get into it, it's a pity, everybody is busy" Project member \#17

Another argues that some employees refrain to participate even as dealers due to lack of overview

"I could see that it would take a long time if I wanted to get a good overview. I probably feel a little bad about putting my shares in one idea and then there are many other ideas, I haven't noticed which I would rather have supported" Project member \#16

Negative learning also occurred. An employee explains that during the first idea competiton he thought it was really funny and contributed with three ideas. Some of his ideas got selected for further development, but afterwards nothing happened.In the second round he prioritized only to play the game for the fun of it arguing that time constraints was crucial.

"You could say I feel I already contributed. I would have liked to post an idea, but I did not get to it, well you know time. It was not my highest priority" Project member \#14 


\section{Creativity and empowerment}

The visibility of the ideas in the Idea Exchange, the commenting and especially the ranking functionality provides for a democratic and transparent innovation process as it gives each employee a voice to bring up ideas, comment and ranking ideas thusinfluencing the process. It provides for open communication across the organization raising new values and ideas..

Concerns with the results of such a democratic ranking made the Innovation Team and Top Management to combine the online democratic ranking with a management based selection of another five ideas. Likewise management was given the final word when nominating the three finalist ideas. There is thus some opening up and letting go of some control by enhancing the transparency of the idea generation process and support a more open communication. However, management is still in control.Pure empowerment might have compromised the need of strategic anchoring of innovation with the business goal, as argued in the following quote:

"When resources are allocated then severity sets in. It would be crazy, well, it is not sure the democracy finds the best idea in relation to The Company business and strategy. It has to be the leaders who decides." Project leader \#18

This is supported by the observation that some of the top ranking ideas in Idea Exchange were not really ideas, but more issues irrelevant for the company strategy. This points to a weakness of the online ranking functionality and how employees decide to buy shares into ideas. It turned out that employees buy shares to support a mix of good, funny and different ideas especially when they are related to their area of expertise as well as ideas from "friends" in the organization.

\section{Innovation influence}

The whole idea and outcome of the Idea Exchange event is to make the employees contribute with ideas that may help to improve the organizational processes based on their working experiences and knowledge Idea Exchange system is a way to disseminate ideas and knowledge about challenges and related solutions. Having the Idea Exchange event is a way to encourage employees to share their ideas about new ways to create value for the company and the customers. The Idea Exchange system seems to be strong in supporting communication about innovations as interesting or funny ideas are often discussed at lunch by employees

"Well regarding this one [a useful idea] a colleague told me about it. Try to look here, it is really good, just something for you." Project manager \#18

\section{Innovation implementation.}

The IdeaExchange concept ensures that at least the winning ideas are implemented. However, the lack of follow up on the majority of the ideas submitted has discouraged some participants (se earlier quote). To address this issue, the Innovation Team had considered of considering Idea Exchange platform as an incubator. An informal way of dissemination and possible implementation is when employees learn about others' ideas and experiences and get in contact with them to implement the ideas in their own project/department (se quote above). 


\section{$5 \quad$ Discussion \& Conclusions}

Our study reveals that idea competition tools may be used to rethink, encourage and eventually create a new/different innovation orientation in companies. As argued by Doherty and Doigh (2003) the idea competition becomes a catalyst not only to implement espoused values but also to develop and rethink the approach to innovation and innovation practice in the organization. In addition it becomes a catalyst as it encourages and inspires innovative behaviors through the different design elements. IdeaExchange architecture and especially the three different roles made it potentially possible for all employees to participate whether or not they see themselves as innovation drivers. This creates a vehicle for exposing and changing the employees awareness of innovation. The idea competition event has created a new innovation orientation due both to the strategic approach behind the call for ideas as well as the allocation of resources for implementation.

Dobni (2010) talks about a weaker or stronger innovation orientation as one common underlying approach within the company. Our study questions this understanding of one unified approach. We observe an innovation orientation with focus on collecting employees ideas for internal process innovations; an innovation orientation which is seen as complementary rather than in opposition to other innovation orientations in the company such as ad hoc innovation (e.g. Gallouj \& Weinstein, 1997) through customer projects or innovation developed by top management. Also this type of innovation orientation is created occasionally as it is argued that it is difficult to create the needed critical mass and focus on an ongoing basis.

\section{$6 \quad$ References}

1. Alam, I., and Perry, C., (2002). "A customer-oriented new service development process."

2. Journal of Services Marketing 16(6), 515-534

3. Andriole, S. J. (2010). "Business Impact of Web 2.0 Technologies," Communications of the ACM 53(12), pp 68-79

4. Bjelland, O. M. and Wood, R. C. (2008). "An Inside View of IBM's Innovation Jam." MIT Sloan Management Review 50(1), pp 32-40

5. Brentani, U. \& Kleinschmidt, E. J. (2004). "Corporate culture and commitment: Impact on performance of international new product development programs". Journal of product innovation management 21 , pp 309-333

6. Bullinger, A. C., Neyer, A-K., Rass, M. \& Moeslein, K. (2010). "Community-based innovation contests: Where competition meets cooperation". Creativity and Innovation management 19(3), pp 290-303

7. Chesbrough, H. W., (2003). Open innovation: The new imperative for creating and profiting from technology. Harvard Business School Press: Boston.

8. Dobni, C. B. (2010)."'The relationship between an innovation orientation and competitive strategy". International journal of innovation management 14(2), pp 331-357

9. Doherty, N. F., and Doig, G. (2003). "An Analysis of the Anticipated Cultural Impacts of the Implementation of Data Warehouses," IEEE Transactions on Engineering Management 50(1), pp. 78-88 
10. Doherty, N. F., and Perry, I. (2001). "The Cultural Impact of Workflow Management Systems in the Financial Services Sector." The Services Industry Journal 21(4), pp 147-166

11. Ebner, W., Leimesister, J. M. \& Kromar, H. (2009). "Community engineering for innovations: the ideas competition as method to nurture a virtual community for innovations". R\&D Management 39(4), pp 342-356

12. Gallouj, F \& Weinstein, O. (1997). "Innovation in services". Research policy (26), pp 537556 Goodman, L. A. (1961). "Snowball sampling." Annuals of Mathematical Statistics 32(1), pp 148-170

13. Hatch, M. J. (1993). “The Dynamics of organizational culture". Academy of Management Review 18(4), pp 657-693

14. Hutter, K., Hautz, J., Füller, J., Mueller, J. and Matzler, K. (2011). "Communitition: The Tension between Competition and Collaboration in Community-Based Design Contests.” Creativity and Management 20(1), pp 3-21

15. Ibrahim, Y. (2010). "The Discourses of Empowerment and Web 2.0: The Dilemmas of User- Generated Content". In S. Murugesan (Ed.), Handbook of Research on Web 2.0, 3.0, and X.0: Technologies, Business, and Social Applications, pp. 828-845

16. Kristensson, P., Matthing, J. and Johansson, N. (2008). "Key strategies in co-creation of new services.” International Journal of Service Industry Management 19(4), pp 474-491

17. Lakhani, K. R., and Kanji, Z. (2008). "Threadless: The Business of Community." Harvard Business School Multimedia/Video Case pp 608-707

18. Markus M.L. (2004). "Technochange management: using IT to drive organizational change," Journal of Information Technology 19(1), pp. 4-20

19. McAfee, A. P. (2006). "Enterprise 2.0: The dawn of emergent collaboration". MIT Sloan management review 47(3), pp 20-28

20. Miles, M.B. and Huberman, A. M. (1994). Qualitative Data Analysis, Thousand Oaks, California: Sage Publications, Second Edition

21. Nambisan, (2002). "Designing virtual customer environments for new product development: Toward a theory." The Academy of Management review 27(33), 392-413

22. Nambisan, S. and Nambisan, P. (2008). "How to profit from a better virtual customer environment." MIT Sloan Management Review 49(3), pp 53-63

23. Piller, F., Schubert, P., Koch, M., and Möslein, K. (2005). "Overcoming mass confusion: Collaborative customer co-design in online communities". Journal of Computer- Mediated Communication 10(4), article 8.

24. Piller, F.T. and Walcher, D. (2006). "Toolkits for idea competitions: A novel method to integrate users in new product development," R\&D Management 36(3), 307-318

25. Pliskin, N., Romm, T., Lee, A. S. and Weber, Y. (1993). "Presumed Versus Actual Organizational Culture: Managerial Implications for Implementation of Information Systems." The Computer Journal 36(2), pp 143-152

26. Schein, E.H. (1985). Organizational culture and leadership. Jossey-Bass, San Francisco Standing, C. and Kiniti, S (2011). "How can organizations use wikis for innovation?'Technovation 31(7), pp 287-295

27. Walsham, G. (1995). "Interpretive case studies in IS research: nature and method." European journal of Information Systems (4), pp. 74-81

28. Wenger, E. (1998). Communities of Practice. Prentice Hall

29. Yin, R.K. (1997). Case Study Research Design and Methods. Thousand Oaks: Sage Publications 